\title{
Learning of Sepak Sila Technique Based Video For Sepak Takraw Course
}

\author{
Silvi Aryanti ${ }^{1}$, Ahmad Richard Victorian ${ }^{2}$, Wahyu Indra Bayu ${ }^{3}$ \\ \{ silviaryanti@fkip.unsri.ac.id ${ }^{1}$, richardvictorian@ @ fkip.unsri.ac.id ${ }^{2}$, wahyu.indra@ fkip.unsri.ac.id ${ }^{3}$ \}
}

Physical Education, Universitas Sriwijaya, South Sumatera, Indonesia ${ }^{1,2,3}$

\begin{abstract}
This study aims to create a learning model of basic techniques of sila based on video of the sepak takraw course for Physical Education students of the Faculty of Teacher Training and Education, Universitas Sriwijaya. The development procedure used in this study used the research and Development method. The research subjects were physical education students. Based on the results of the stage I media expert validation, the percentage was 73.2. The results of the validation of sepak takraw for the first stage of obtained a percentage of 71.4 in the fairly decent category. Based on the results of expert validation, the average percentage of the assessment was 72.3. The implication of this research is that the research product is quite feasible to use.
\end{abstract}

Keywords: Sepak Sila, Sepak Takraw Learning, Video

\section{Introduction}

One of the basic techniques of Sepak Takraw that must be mastered by students of the faculty of teacher training and education at Universitas Sriwijaya is the technique of sepak sila. Sepak sila is used to serve and pass the ball to the opposing side. Saputro \& Supriyadi, sepak sila is the most basic technique that must be mastered. This is because most of the sepaktakraw games use the technique of sepak sila to receive the ball and pass the ball [1]. Qoryaningtyas, besides being a basic technique in the Sepaktakraw game, soccer sila is also the key to playing the game, including passing for smashes, passing and serving, and if the technique of sila football is well mastered it will be easier to receive the ball from opponent attacks [2].

Lecture material in the physical education study program of the Faculty of Teacher Training and Education, Universitas Sriwijaya, namely the basic skills of Sepaktakraw with a weight of 2 credits. Based on observations in the field, the second semester students of the physical education and health study program have difficulty understanding and practicing the material about basic techniques of sepak sila in the sepak takraw course. At the time of practice students have not mastered the basic techniques of sepaksila, and when giving material in class only provides material that is theoretical, the learning model in the form of videos is not given in detail. This causes learning to be monotonous and students' understanding of the material is not very clear.

Achievement of student learning outcomes is influenced by choosing the right learning model. Models for learning in the application of learning must be implemented in accordance with the needs and characteristics of students. Aryanti., Victorian, and Yusfi, choosing the right learning technique is needed by a teacher. It aims to improve student learning outcomes [3]. According to Fuad., Zubaidah., Mahanal., \& Suarsini, the main factor determined the increase in the quality of teaching in schools is the needs and interests of teachers during implementation, innovative models in teaching. The main factor that determines the improvement in the quality of teaching in schools is the needs and interests of teachers when implementing innovative learning models in teaching [4]. The relevant research by Faizin shows that there are differences in the 
results of learning football with the application of using a learning model, namely the cooperative Student Teams Achievement Division (STAD) type in learning football sila elementary Pademonegoro class V [5]. Nur et al. in his research, it shows that there is an effect of the direct learning model on the mastery of the Sepak Takraw technique with an increase of $61.02 \%$. There is also the influence of the cooperative learning model on the basic techniques of Sepak Takraw with an increase of $46.43 \%$. However, the direct learning model is more effective in mastering the basic techniques of Sepak Takraw than the cooperative learning model, with a post-test mean difference of 2.889 [6].

Choosing the right learning model for students is believed to be able to help convey messages correctly, effectively, efficiently, can create and enrich learning experiences, be able to present a picture of an event as close or real as possible, and be able to increase student activity and skills. This is so that the learning objectives can be achieved properly. Variations in the learning model can use video to make understanding easier for students. The use of video-based sepak sila learning models for physical education students is needed. This aims to achieve learning objectives. Daryanto, Media Video aims to help the learning process be better for mass learning, individually or in groups. Mass learning, the benefits of video media are very real. Perez, Video a is used for teachers to reflect and train. Therefore, video analysis can support one's reflection and teaching can be improved [7].

Based on the problems that exist in the field, the researchers are interested in conducting research on the Sepak Sila Technique Learning Model Based on the Video Course of Sepak Takraw.

\section{Method}

This research is a research and development research. These steps were adapted into the following for design research and development procedures:

a. Information gathering in the field

Literature review and field studies are carried out first at this stage. Learning is carried out by tracing the learning model literature, basic techniques of precepts, learning approaches using video, and science, technology, engineering and mathematics (STEM). Literature in the form of journals, research results, and football handbooks.

b. Analyze the information that has been collected

Needs analysis is carried out by studying the available resources in the study program which is planned to be a research site in the Faculty of Teacher Training and Education, Universitas Sriwijaya. Needs analysis in the soccer precepts learning model in the course Sepak Takraw.

c. Early product development (Draft Model)

The third stage is the making of the initial draft of the product in the form of a video-based basic technique of learning model, after the next analysis process is the product stage that can be useful and help lecturers in learning and learning activities.

(a) Expert Validation

The fourth stage of Expert Validation, before a small-scale trial is carried out on the initial product, the product must receive validation from material experts, namely: (a) Sepak takraw learning expert and (b) media expert. The validation process can get input on the initial product.

The eligibility categories according to Arikunto [8] are:

Table 1. Eligibility Categories

\begin{tabular}{ll}
\hline \multicolumn{1}{c}{ Score in percentage } & \multicolumn{1}{c}{ Eligibility Category } \\
\hline$<40 \%$ & Not good / unworthy \\
$40 \%-55 \%$ & Not Good / Not Feasible \\
$56 \%-75 \%$ & Good Enough / Decent Enough \\
$76 \%-100 \%$ & Good / Worth it \\
\hline
\end{tabular}




\section{Results and Discussion}

The purpose of this study was to create a model for learning basic techniques of sila based on video of the sepak takraw course for students of the unsri faculty of physical education. The research product was in the form of a video-based learning model of basic soccer techniques.

\subsection{Results}

Research learning of sepak sila technique based video for sepak takraw course is validated by experts in their fields, namely a media expert, an expert on football material.

a.The Results of Media Expert's Validation

Table 2. Results of the Media Expert Validation Stage I

\begin{tabular}{lllll}
\hline Code & $\Sigma$ & $\begin{array}{l}\text { Score } \\
\text { Maximum }\end{array}$ & $(\%)$ & Category \\
\hline APB & 41 & 56 & 73.2 & Decent enough \\
\hline
\end{tabular}

$$
\begin{aligned}
\text { Percentage }=\text { Total } / \text { Score Maximum } \\
=41 / 56 \times 100 \\
=\mathbf{7 3 . 2}
\end{aligned}
$$

The first stage of validation obtained a percentage of 73.2 so it was stated that according to the media expert, the category was "quite feasible".

b. The Results of Sepak Takraw Expert's Validation

Table 3. Validation Results of Sepak Takraw Game Expert Stage I

\begin{tabular}{cccccc}
\hline No & Code & $\Sigma$ & $\begin{array}{c}\text { Score } \\
\text { Maximum }\end{array}$ & $\%$ & Category \\
1 & APB & 20 & 28 & 71.4 & Decent enough \\
\hline
\end{tabular}

$$
\begin{aligned}
\text { Percentage } & =\text { Total } / \text { Score Maximum } \\
& =20 / 28 \times 100 \\
& =\mathbf{7 1 . 4}
\end{aligned}
$$

The first stage of validation obtained a percentage of 71.4 so that it can be stated that according to the Sepak Takraw expert, the video-based soccer learning model is in the "quite feasible" category.

c.The Average Percentage Result of the Assessment

Table 4. The Average Percentage Result of the Assessment

\begin{tabular}{llc}
\hline No & \multicolumn{1}{c}{ Validation } & Results \\
\hline 1 & Media Expert's & 73.2 \\
2 & Sepak Takraw Game Expert & 71.4 \\
3 & Average Percentage Result & $\mathbf{7 2 . 3}$ \\
\hline
\end{tabular}

Based on the results of the 2 experts in stage I the average percentage was 72.3 . So, the research product in the form of a video-based sepak sila learning model is quite feasible to be used in learning Sepak Takraw.

\subsection{Discussion}

Based on the results of the validation by media experts and sepak takraw game experts, the average percentage was 72.3. This shows that the video-based sepak sila learning model is quite feasible to use in learning sepak takraw. The research product in the form of a video-based learning model with implementation instructions and the target of students was correct. Roche \& Gal-Petitfaux, in their research shows the potential effects of using $360^{\circ}$ video in teacher 
education. The two main results that can be seen are: 1) The use of $360^{\circ}$ videos allows the preservice teacher to live an immersive experience. 2) The use of $360^{\circ}$ video must be used with a wide-angle or point of view to understand the situation in depth [9]. Semarayasa revealed that the use of video is used in the learning process because it can provide more space for students to become independent learning and improve their independent learning abilities. In addition, it can assist students in achieving maximum competencies and skills. Through videos, they can develop awareness to assess strengths and weaknesses. These useful insights are provided not only for the students themselves, but also for the teachers / trainers [10]. Major, a consistent finding is that video is effective when used as part of teacher professional development. Since studies largely use thematic qualitative analysis, however, this consensus needs further examination [11].

Models for learning can have a positive impact on students in learning. The learning model using video can provide student learning motivation and improve learning outcomes. Therefore, the video-based football learning model can be used for learning Sepak Takraw.

\section{Conclusion}

Learning using video can provide good benefits for students in understanding the learning material, namely the soccer precepts technique. The results of the stage I media expert validation, the percentage was 73.2. The results of the validation of sepak takraw for the first stage of obtained a percentage of 71.4 in the fairly decent category. Based on the results of expert validation, the average percentage of the assessment was 72.3. The implication of this research is that the research product is quite feasible to use.

Acknowledgments. Thanks to the rector of Universitas Sriwijaya, This research was funded by the Public Service Agency DIPA Budget Universitas Sriwijaya 2020 Fiscal Year No. SP DIPA023.17.2.677515 / 2020, Revision to 01 dated March 16, 2020 In accordance with the Chancellor's Decree Number: 0684 / UN9 / SK.BUK.KP / 2020, and all those who have helped.

\section{References}

[1] Saputro, D. B., \& Supriyadi, S. Pengembangan Variasi Latihan Sepak Sila Sepak Takraw untuk Tingkat Pemula. Indonesia Performance Journal. 2017. 1(2), 112-118.

[2] Qoryatiningtyas, U., Winarno, M. W. M., \& Surendra, M. Pengembangan Variasi Latihan Sepak Sila Untuk Peserta Ekstrakurikuler Sepaktakraw di Sd Negeri Wonodadi 1 Kecamatan Wonodadi Kabupaten Blitar. Gelanggang Pendidikan Jasmani Indonesia. 2017. 1(1), 103-113.

[3] Aryanti, S., Victorian, A. R., \& Yusfi, H. Pengembangan Teknik Pembelajaran Servis Forehand Bulutangkis Bagi Siswa Putra Sekolah Menengah Atas. Sebatik. 2018. 22(2), 181-187.

[4] Fuad, N. M., Zubaidah, S., Mahanal, S., \& Suarsini, E. Improving Junior High Schools' Critical Thinking Skills Based on Test Three Different Models of Learning. International Journal of Instruction. 2017. 10(1), 101-116.

[5] Faizin, M. Penerapan Model Pembelajaran Kooperatif Tipe Student Teams Achievment Division (STAD) Terhadap Hasil Belajar Sepak Sila Pada Sepak Takraw (Studi pada siswa kelas V SDN Pademonegoro Sidoarjo). Jurnal Pendidikan Olahraga dan Kesehatan. 2014. 2 (3).

[6] Nur, H., Sepriadi, S., \& Zulman, Z. The Effect of Direct Learning Model and Cooperative Learning Model on The Mastery of Basic Techniques in Sepak Takraw. 3rd International Conference on Sports Science, Health and Recreation. 2018.

[7] Pérez-Torregrosa, A. B., Díaz-Martín, C., \& Ibáñez-Cubillas, P. The use of video annotation tools in teacher training. Procedia-Social and Behavioral Sciences. 2017. 237, 458-464.

[8] Arikunto, S. Prosedur Penelitian Suatu Pendekatan Praktik. Edisi Revisi 6. Jakarta: Rineka Cipta. 2009.

[9] Roche, L. \& Gal-Petitfaux, N. Using $360^{\circ}$ video in Physical Education Teacher Education. In P. Resta \& S. Smith (Eds.), Proceedings of Society for Information Technology \& Teacher Education International Conference. Austin, TX, United States: Association for the Advancement of Computing in Education (AACE). 2017. pp. 3420-3425.

[10] Semarayasa, I. K. Utilizing mobile phone video in teaching sepak takraw gunting spike. The 2nd International Seminar on Educational Technology 2016. 2016. p. 428. 
[11] Major, L., \& Watson, S. Using Video to Support In-Service Teacher Professional Development: The State of The Field, Limitations and Possibilities. Technology, Pedagogy and Education. 2018. 27(1), 49-68. 